\title{
IMPLEMENTASI LAYANAN BIMBINGAN KONSELING ISLAMI MELALUI TEKNIK HIPNOTERAPI DALAM MEMBENTUK KARAKTER SISWA
}

\author{
Masdudi \\ IAIN Syekh Nurjati Cirebon \\ masdudi.bandung@gmail.com
}

\begin{abstract}
Abstrak
Guru dan guru BK harus peka terhadap perubahan-perubahan yang terjadi dalam proses pembelajaran. Banyaknya siswa yang berprilaku tidak normatif yang dipengaruhi oleh kreativitas guru dalam mengembangkan pendekatan dan teknik pembelajaran, sehingga memunculkan masalah psikologis dan gejala psikosomatis. Masih banyak guru BK yang belum mampu mengembangkan pendekatan dan teknik yang sesuai. Untuk mencari solusi menyelesaikan masalah khususnya masalah psikhis dan dalam membentuk karakter siswa, penulis menawarkan sebuah solusi yaitu penelitian tentang pendekatan hypno therapy dalam proses bimbingan konseling. Masalah dalam penelitian ini berkaitan dengan implementasi teknik hypno therapy dalam proses bimbingan konseling islami di sekolah dalam pembentukan karakter siswa di sekolah. Metode penelitian ini menggunakan jenis penelitian deskriptif kualitatif. Subjek penelitian adalah terapis yang terlibat langsung yaitu peneliti dibantu oleh guru BK untuk menjadi mediasi dalam proses konseling melalui teknik hipnoterapi. Sedangkan objek penelitiannya adalah sebagian siswa yang mempunyai masalah psikologis dengan penerapan konseling kelompok dan konseling individu. Hasil temuan penelitian, bahwa penerapan teknik layanan bimbingan konseling islami di sekolah sangat membantu mengidentifikasi, merumuskan dan menemukan secara cepat solusi masalah bagi siswa. Teknik hipnoterapi dalam bimbingan konseling islami sangat berdampak terhadap karakter siswa karena banyak siswa yang merasakan suatu perubahan. Faktor yang menjadi pendukung penerapan teknik ini adalah ketersediaan pihak sekolah dan siswa untuk melakukan proses konseling secara inten karena sangat membantu dalam menyelesaikan masalahmasalah siswa. Faktor penghambatnya adalah kedua orangtuanya, ayah dan ibu, tidak bersedia bertemu terapis untuk menjalani sesi wawancara mendalam dan konseling. Saran untuk lembaga sekolah adalah perlunya pihak sekolah untuk memfasilitasi guru BK atau konselor dalam pengembangan dan pelatihan teknik hipnoterapi atau mendatangkan ahli, sehingga guru BK mempunyai kemampuan dalam menangani masalah-masalah siswa. Pihak sekolah harus melakukan kerjasama yang intensif dan kontinu dengan orang tua dalam penanganan siswa yang bermasalah, sehingga penerapan teknik hipnoterapi bisa membantu menangani masalah-masalah belajar yang dihadapi anaknya.
\end{abstract}

Kata Kunci: Bimbingan Konseling, Hipnoterapi, Karakter 


\begin{abstract}
Teachers and BK teachers must be sensitive to changes that occur in the learning process. The number of students who behave in a non-normative manner is influenced by the creativity of the teacher in developing learning approaches and techniques, thus giving rise to psychological problems and psychosomatic symptoms. There are still many BK teachers who have not been able to develop appropriate approaches and techniques. To find solutions to solve problems, especially psychological problems and in shaping the character of students, the authors offer a solution that is research on the hypno therapy approach in the process of counseling guidance. The problem in this study relates to the implementation of hypno therapy techniques in the process of counseling Islamic counseling in schools in character building students in schools. This research method uses qualitative descriptive research. Research subjects were therapists who were directly involved, namely researchers assisted by BK teachers to be mediated in the counseling process through hypnotherapy techniques. While the object of research is some students who have psychological problems with the application of group counseling and individual counseling. The findings of the study, that the application of Islamic counseling counseling service techniques in schools is very helpful in identifying, formulating and quickly finding solutions to problems for students. Hypnotherapy techniques in the counseling of Islamic counseling greatly affect the character of students because many students feel a change. The factor that supports the application of this technique is the availability of the school and students to conduct the counseling process intensively because it is very helpful in solving student problems. The inhibiting factors are both parents, father and mother, not willing to meet the therapist to undergo in-depth interview sessions and counseling. Suggestions for school institutions are the need for the school to facilitate counselors or counselors in the development and training of hypnotherapy techniques or bring in experts, so that the BK teacher has the ability to handle student problems. The school must carry out intensive and continuous collaboration with parents in handling problematic students, so the application of hypnotherapy techniques can help deal with the learning problems faced by their children.
\end{abstract}

Keywords: Counseling Guidance, Hypnotherapy, Character

\title{
A. PENDAHULUAN
}

\section{Latar Belakang Masalah}

Konselor berperan sebagai motor penggerak dan model di lingkungan sekolah maupun masyarakat secara ideal harus memiliki kompetensi dan kreativitas yang tinggi dalam melaksanakan proses konseling terutama saat menemukan masalah dalam pembelajaranya. Kreativitas

guru diartikan kemampuan seorang guru untuk membelajarkan siswanya 
dengan kemampuan yang diiringi sikap kreatif dan keingintahuan yang tinggi, keberanian mengambil resiko, tertantang oleh kemajemukan, imajinatif, serta menghasilkan produk yang kreatif dalam pembelajaran.

Masih banyak guru termasuk guru BK yang belum melaksanakan salah satu perannya yang begitu penting, yaitu sebagai peneliti (reseacher) dalam rangka meningkatkan kemampuan dan keterampilanya dalam mengajar. Saat konselor menemukan masalah dalam pembelajaran, khususnya dengan anak didiknya, seperti ribut di dalam kelas saat pembelajaran berlangsung, rendahnya hasil belajar, kurangnya motivasi belajar, sehingga hal ini akan berdampak kepada kualitas output pendidikan yang menurun, dan yang lebih memprihatinkan lagi jika tujuan inti dari pembelajaran tidak terpenuhi sama sekali yaitu perubahan perilaku (Mohamad Surya, 2004: 8).

Suatu kondisi yang cukup rumit, mengingat tugas tersebut sudah mendarah daging (habitual performance) bagi para konselor sekolah sebagai pelaksana kesehariannya, namun di pihak lain ternyata kinerja yang tampak belum sesuai dengan harapan. Bukti secara empiris menunjukkan masih banyak siswa yang belum bisa berperilaku secara normatif, antara lain mulai dari berperilaku tidak sopan, berbohong (termasuk membolos), membuat onar, berkelahi, sampai dengan berperilaku melanggar norma kesusilaan, malas belajar, tidak mau/mogok sekolah, tidak mau berteman dengan kawankawannya, pemurung, pemarah, melawan orang tua, kebiasaan jelek, kecanduan Game, dan lain-lain. Hal ini terjadi antara lain dari sisi peran yang semestinya dilakukan oleh seorang konselor sekolah dalam pengembangan aspek pribadi dan sosial siswa yang belum maksimal. Walaupun konselor sekolah bukan sebagai satu-satunya pihak yang harus atau paling bertanggung jawab terhadap kondisi tersebut, namun konselor sekolah tidak bisa lepas dari tanggung jawab tersebut. Banyak guru BK yang apatis dan tidak mau melakukan suatu tindakan berupa penelitian untuk mencari solusi atas permasalahan-permasalahan tersebut.

Sudah banyak solusi yang ditawarkan dalam mengembangkan teknik proses bimbingan konseling, diantaranya pendekatan hypno teaching. Namun penulis menawarkan sebuah solusi lain yaitu pendekatan hypno therapy 
dalam proses konseling untuk membentuk karakter siswa. Di kalangan dunia pendidikan pendekatan ini belum resmi dan populer dipakai atau diakui sebagai sebuah pendekatan, namun sebenarnya pendekatan ini sudah sering diaplikasikan oleh para pendidik atau konselor yang menguasai teknik hipnosis, karena pendekatan ini mencoba menggunakan praktek hipnosis dalam pembelajaran dan untuk kepentingan pembelajaran.

Pendekatan hypno therapy merupakan suatu teknik yang efektif dan efesien untuk menghantarkan informasi ke dalam pikiran bawah sadar. Hypno terapy merupakan perpaduan dari konsep aktivitas belajar mengajar dengan ilmu hipnosis. Dalam proses pembelajaran akan terasa lebih menyenangkan, damai, tenang, rileks, dan kaya akan makna sugestif dalam pembelajaran di kelas tanpa harus mengurangi hakekat dari tujuan kurikulum. Teknik hypno therapy bersifat kuratif artinya mencari solusi dengan menggunakan terapi setelah proses pembelajaran, biasanya gejala yang muncul susah untuk belajar, tidak rileks, ngantuk, tidak semangat, cemas, phobia, gelisah dll, dan teknik ini masuk kategori konseling islami. Penggunaan teknik hypno therapy hanya bisa di lakukan oleh peneliti yang paham dan punya keahlian tentang ilmu hipnosis atau dengan mendatangkan pakar hipnosis.

Dalam teknik ini, konselor berperan sebagai hipnosis sementara siswa selaku suyet (orang yang dihipnosis), konselor selaku hipnosis (orang yang menghipnosis) perlu menidurkan anak didiknya ketika memberi sugesti. Selain itu konselor juga harus menggunakan bahasa persuasif sebagai alat komunikasi yang dapat mensugesti siswa secara efektif. Gunakanlah bahasa komunikasi yang sesuai dengan harapan siswa. Dalam arti turunkan gelombang otak siswa dari beta menjadi alpha atau tetha.

\section{Rumusan Masalah}

Berdasarkan uraian tentang latar belakang dan problematika sebagaimana dikemukakan di atas sebagai indikator penelitian ini diharapkan dapat muncul jawaban terhadap pertanyaan, adalah sebagai berikut:

a. Bagaimanakah implementasi teknik hypno therapy dalam proses bimbingan konseling islami di sekolah? 
b. Faktor-faktor apa saja yang menjadi pendukung dan penghambat implementasi teknik hypno therapy dalam proses bimbingan konseling islami di sekolah?

c. Seberapa jauh dampak keberhasilan implementasi teknik hypno therapy dalam bimbingan konseling islami dapat membentuk karakter siswa di sekolah?

\section{Tujuan}

Tujuan penelitian ini adalah:

a. Mengetahui implementasi teknik hypno therapy dalam proses bimbingan konseling islami di sekolah

b. Mengidentifikasi faktor-faktor yang menjadi pendukung dan penghambat implementasi teknik hypno therapy dalam proses bimbingan konseling islami di sekolah

c. Mengetahui dampak keberhasilan implementasi teknik hypno therapy bimbingan konseling islami dalam membentuk karakter siswa

\section{B. KAJIAN TEORI}

\section{Konsep Bimbingan dan Konseling Islami}

Bimbingan Islami merupakan proses pemberian bantuan, artinya bimbingan tidak menentukan atau mengharuskan, melainkan sekedar membantu individu. Individu dibantu, dibimbing agar mampu hidup selaras dengan ketentuan dan petunjuk Allah. Artinya individu menyadari eksistensi diri sebagai makhluk Allah yang diciptakan Allah untuk mengabdi kepadaNya; mengabdi dalam arti seluas-luasnya. Dengan menyadari eksistensinya sebagai makhluk Allah, berarti yang bersangkutan dalam hidupnya akan berprilaku yang tidak keluar dari ketentuan dan petunjuk Allah, dengan hidup serupa ini maka akan tercapailah kehidupan di dunia dan akherat yang menjadi idaman setiap muslim. (Aunur Rahim Faqih, 2004:6)

Bimbingan Islami membantu individu memiliki kemampuan agar dapat hidup selaras dengan ketentuan dan petunjuk Allah sehingga akan menyadari eksistensi dirinya sebagai mahluk Allah dan mengabdi kepada Allah. Kesadaran terhadap eksistensi diri sebagai mahluk Allah SWT menjadikan 
hidup individu senantiasa berperilaku tidak keluar dari ketentuan dan petunjuk Allah sehingga tercapai kebahagaian dunia dan akherat. Bimbingan Islami mengajak individu untuk melakukan hubungan baik dengan pencipta alam semesta Allah SWT.

Konseling Islami adalah proses pemberian bantuan kepada individu agar menyadari kembali eksistensinya sebagai makhluk Allah yang seharusnya dalam kehidupan keagamaannya senantiasa selaras dengan ketentuan dan petunjuk Allah, sehingga dapat mencapai kebahagiaan hidup di dunia dan akherat (Aunur Rahim Faqih, 2004:63).

Dapatlah dipahami bahwa konseling perspektif Islam adalah proses bantuan dalam upaya membantu individu untuk menumbuhkan serta mengembangkan kesadaran akan eksistensi dirinya sebagai hamba Allah secara profesional dalam jangka waktu tertentu sehingga individu mempunyai tanggungjawab terhadap dirinya dan juga terhadap lingkungan sekitar untuk mencapai kebahagiaan serta ketenangan hidup di dunia dan akherat.

Seperti yang telah diketahui, konseling tekanannya pada upaya kuratif atau pemecahan masalah yang dihadapi seseorang. Secara Islami, konseling berarti membantu individu menyadari kembali keberadaan atau eksistensinya sebagai makhluk Allah untuk senantiasa mengabdi kepada-Nya. Artinya menyadari bahwa di dalam dirinya Allah telah menyertakan fitrah untuk beragama Islam dan menjalankannya dengan sebaik-baiknya. Dengan demikian, permasalahan apapun senantiasa akan dikembalikan pada petunjuk Allah dan anjuran Rasulullah, karena selama tidak menyimpang dari ketentuan dan petunjuk Allah tersebut, maka tidak akan pernah ada problem/masalah dalam kehidupannya.

Menurut W.S. Winkel (1997:198-199) kualitas kepribadian konselor yaitu mengenal diri sendiri (knowing one self), memahami orang lain (understending others) dan kemampuan berkomunikasi dengan orang lain (relating to others). Sedangkan Muhammad Surya (2003:58-67) mengemukakan beberapa karakteristik kepribadian konselor antara lain: pengetahuan mengenai diri sendiri (self knowledge), kompetensi, kesehatan psikologis yang baik, dapat dipercaya, kejujuran, kekuatan daya (strength), 
kehangatan, pendengar yang aktif, kesabaran, kepekaan, kebebasan, kesadaran holistik.

\section{Konsep Hipnoterapi dalam Bimbingan Konseling Islami}

Dalam proses konseling, hipnoterapi bisa dilakukan sebagai terapi individual dan kelompok. Secara klinis, apabila induksi diberikan oleh orang yang berpengalaman, induksi untuk pengeluaran muatan memori traumatik yang tersimpan di otak di dalam terapi kelompok bisa sangat efektif. Seperti yang sering terlihat dalam kelompok-kelompok doa dan majelis, para pesertanya menjadi menangis bersama-sama dan bahkan berteriak, saat pemimpin doa membacakan doa permohonan yang menyayat-nyayat hati.

Hipnoterapi adalah salah satu cabang ilmu psikologi yang mempelajari manfaat sugesti untuk mengatasi masalah pikiran, perasaan dan perilaku. Hipnoterapi dapat juga dikatakan sebagai suatu teknik terapi pikiran dan penyembuhan yang menggunakan metode hipnotis untuk memberi sugesti atau perintah positif kepada pikiran bawah sadar untuk penyembuhan suatu gangguan psikologis atau untuk mengubah pikiran, perasaan, dan perilaku menjadi lebih baik. Orang yang ahli dalam menggunakan hipnotis untuk terapi disebut "hypnotherapist". Hipnoterapi menggunakan pengaruh kata - kata yang disampaikan dengan teknik - teknik tertentu. Satu-satunya kekuatan dalam hipnoterapi adalah komunikasi. (Kahija YF., 2007).

Tujuan Hipnoterapi adalah menyelesaikan masalah atau meningkatkan kemampuan diri, yang mana hasil dari hipnoterapi diharapkan bisa bertahan untuk selamanya. Dalam hipnoterapi, klien dan hypnotherapist bekerja sama untuk meraih tujuan. Pasien atau klien tidak akan dibuat tidak sadar atau tidak berdaya, melainkan akan dibimbing supaya bisa menyadari kekuatan diri sendiri sehingga dengan menggunakan kebijaksanaan dan kekuatan Pikiran Bawah Sadar masalah yang dialami bisa diatasi sendiri. Metode hipnoterapi modern dengan orientasi kepada pasien lebih banyak berperan untuk 'membuka' kesadaran pasien untuk mengetahui masalah utamanya dan membantu pasien untuk menyembuhkan atau menyelesaikan masalahnya oleh dia sendiri. Pasien menjadi lebih merasa nyaman dengan kondisinya dan dapat menerima kondisinya, sehingga tidak mengganggu aktivitasnya atau 
kegiatannya sehari-hari. Jadi hipnoterapi adalah aplikasi hipnotis untuk terapi pengobatan. (Syaputra MD., 2008).

C. Roy Hunter MS. (2015:4) mendefinisikan hipnoterapi sebagai teknik hipnosis untuk meningkatkan pencapaian tujuan, meningkatkan motivasi atau perubahan, meningkatkan pertumbuhan pribadi atau spiritual dan atau melepaskan klien dari masalah dan penyebab masalah. Singkatnya penghipnotis hanya memberikan berbagi sugesti dan berharap mendapatkan hasilnya, sedangkan hipnoterapis tahu cara membujuk bawah sadar untuk melepaskan penyebab supaya bisa memfasilitasi pelepasan dan pembelajaran ulang dan memecahkan masalah.

Di bidang pendidikan dan pengembangan diri, hipnoterapi berperan pada penyiapan/penguatan prasyarat belajar, yakni kondisi emosi dan mental seorang pembelajar. Sebelum seseorang men-setting pembelajarannya, ia harus terlebih dahulu menyiapkan prasyaratnya. Kondisi mental atau emosi yang kurang stabil, masalah persepsi terhadap belajar/pendidikan, mental blocking, “programming” yang keliru, trauma masa lalu, pengalaman kurang mengenakkan, perasaan tercemoohkan, merasa direndahkan, dsb, itu mengganggu pembelajaran yang bisa muncul kadang berupa kemalasan tanpa diketahui penyebabnya, kurang motivasi dan kurang percaya diri. Hipnoterapi berperan di sini, yakni melepas emosi-emosi negatif tersebut. Jika prasyarat utama ini telah beres barulah beranjak ke proses belajar yang sesuai dengan minat dan kebutuhan.

Psikoterapi adalah perawatan dengan menggunakan alat-alat psikologis terhadap permasalahan yang berasal dari kehidupan emosional dimana seseorang secara sengaja menciptakan hubungan profesional dengan klien, yang bertujuan: (1) menghilangkan, mengubah atau menemukan gejala-gejala yang ada; (2) memperantai (perbaikan) pola tingkah laku yang rusak; (3) meningkatkan pertumbuhan dan perkembangan kepribadian (Abdul Azis Ahyadi, 1991:156).

Dari pernyataan di atas semakian jelas bahwa psikoterapi Islam adalah proses pengobatan dan penyembuhan suatu penyakit, baik penyakit fisik, mental, moral maupun spiritual yang dilakukan oleh seorang terapis dengan 
latar belakang ilmu perilaku dan teknik-teknik usaha yang dikembangkan dengan melalui bimbingan Al-Quran dan As-Sunnah yang bertujuan untuk mengembalikan, memelihara, menjaga dan mengembangkan kondisi klien agar akal dan hatinya berada dalam kondisi dan posisi sebagai fitrahnya.

Dalam proses hipnoterapi ada unsur relaksasi, dimana proses ini bisa diiringi dengan berdoa dan dzikir. Ketika dalam keadaan relaksasi, otak menampakkan gelombang alfa, dimana kondisinya dalam keadaan rileks, tetapi siaga melakukan sesuatu. Untuk merelaksasikan diri bisa melalui duduk tafakur dan berdzikir, dimana hal ini dapat membangkitkan respon relaksasi.

\section{Faktor-faktor Yang Mempengaruhi Munculnya Masalah Pada Siswa}

Sekolah merupakan tempat instansi formal yang dijadikan tempat belajar bagi para siswa-siswanya. Sekolah terdiri dari berbagai karakter siswa yang berbeda-beda, perbedaan karakter siswa ini jelas terjadi karena perbedaan cara pandang dalam hidup mereka. Dalam kehidupannya, siswa-siswa ini tidak lepas dari segala macam masalah yang harus dihadapinya. Masalahnya pun beragam, hal tersebut merupakan pengertian dari siswa bermasalah. Siswa di sekolah sebagai manusia (individu) dapat dipastikan memiliki masalah, tetapi kompleksitas masalah-masalah yang dihadapi oleh individu yang satu dengan lainnya berbeda-beda. Siswa di sekolah akan mengalami masalah-masalah yang berkenaan dengan : pertama, perkembangan individu; kedua, perbedaan individu dalam hal kecerdasan, kecakapan, hasil belajar, sikap, bakat, kebiasaan, pengetahuan, kepribadian, minat, ciri-ciri jasmaniah, dan latar belakang lingkungan; ketiga, kebutuhan individu dalam hal memperoleh kasih sayang, memperoleh harga diri, memperoleh penghargaan yang sama; keempat penyesuaian diri dan kelainan tingkah laku; Kelima, masalah belajar.

Hamdan Bakran Adz-Dzaky yang dikutip Tohirin mengklasifikasikan masalah individu atau siswa sebagai berikut :

a. Masalah individu yang berhubungan dengan Tuhan-Nya, ialah kegagalan individu melakukan hubungan secara vertikal dengan Tuhan-Nya; seperti sulit menghadirkan rasa takut, memiliki rasa tidak bersalah atas dosa yang telah dilakukan, sulit menghadirkan rasa taat, merasa bahwa Tuhan senantiasa mengawasi perilakunya sehingga individu merasa tidak memiliki 
kebebasan. Dampak semuanya itu adalah timbulnya rasa malas atau enggan melaksanakan ibadah dan sulit untuk meninggalkan perbuatan-perbuatan yang dilarang Tuhan.

b. Masalah individu berhubungan dengan dirinya sendiri adalah kegagalan bersikap disiplin dan bersahabat dengan hati nurani yang selalu mengajak atau menyeru dan membimbing kepada kebaikan dan kebenaran TuhanNya. Dampaknya adalah muncul sikap was-was, ragu-ragu, rendah motivasi dan dalam banyak hal tidak mampu bersikap mandiri.

c. Masalah individu berhubungan dengan lingkungan keluarga, misalnya kesulitan atau ketidakmampuan mewujudkan hubungan yang harmonis antara anggota keluarga seperti antara anak dengan ayah dan ibu, adik dengan kakak dan saudara-saudara lainnya. Kondisi ketidakharmonisan dalam keluarga menyebabkan anak merasa tertekan, kurang kasih sayang dan kurangnya ketauladanan dari kedua orang tuanya.

d. Masalah individu yang berhubungan dengan lingkungan kerja, misalnya kegagalan individu memilih pekerjaan yang sesuai dengan karakteristik pribadinya, kegagalan dalam meningkatkan prestasi kerja, ketidakmampuan berkomunikasi dengan atasan, rekan kerja dan kegagalan melaksanakan pekerjaan yang menjadi tugas dan tanggung jawabnya. Khususnya siswa, masalah yang berhubungan dengan karier misalnya ketidakmampuan memahami tentang karier, kegagalan memilih karier yang sesuai dengan latar belakang pendidikan dan karakteristik pribadinya.

e. Masalah individu yang berhubungan dengan masalah lingkungan sosialnya misalnya ketidakmampuan melakukan penyesuaian diri (adaptasi) baik dengan lingkungan tetangga, sekolah dan masyarakat atau kegagalan bergaul dengan lingkungan yang beraneka ragam watak, sifat dan perilaku.

Di sekolah sangat mungkin ditemukan siswa yang bermasalah, dengan menunjukan gejala penyimpangan perilaku. Upaya untuk menangani siswa bermasalah, khususnya yang terkait dengan pelanggaran disiplin sekolah menurut Masdudi (2015:63) dapat dilakukan melalui dua pendekatan, yaitu: (1) pendekatan disiplin; (2) pendekatan bimbingan dan konseling. 


\section{Bimbingan Konseling dan Pembentukan Karakter Siswa}

Lickona (2004) mengemukakan bahwa proses pendidikan karakter menekankan kepada tiga komponen karakter yang baik (components of good character) yakni moral knowing, moral feeling dan moral action. Dalam konteks proses pendidikan karakter di sekolah, tahapan moral knowing disampaikan dalam dimensi kelas dan dimensi komunitas oleh guru. Adapun moral feeling dikembangkan melalui pengalaman langsung para siswa dalam konteks sosial dan personalnya. Aspek emosi yang ditekankan untuk dirasakan para siswa meliputi sembilan pilar pendidikan karakter, khususnya pilar rasa cinta Allah dan segenap ciptaanya. Sedangkan moral action meliputi setiap upaya sekolah dalam rangka menjadikan pilar pendidikan karakter rasa cinta Allah dan segenap ciptaanya diwujudkan menjadi tindakan nyata. Hal tersebut diwujudkan melalui serangkaian program pembiasaan melakukan perbuatan yang bernilai baik menurut parameter Allah swt di lingkungan sekolah. Dalam mewujudkan moral action, sekolah memperhatikan tiga aspek lainnya terkait dengan upaya perwujudan materi pendidikan menjadi karakter pada diri siswa, ketiga aspek tersebut meliputi kompetensi, keinginan dan kebiasaan. Pembentukan ketiga aspek tersebut diupayakan oleh guru secara terpadu dan konsisten yang pada akhirnya diharapkan melahirkan moral action yang secara spontan dilakukan anak, baik di lingkungan sekolah, keluarga, maupun di lingkungan masyarakat.

Kontribusi pengembangan karakter dalam suatu sistem pendidikan di sekolah melalui teknik hipnoterapi dalam konseling merupakan keterkaitan antara komponen-komponen karakter yang mengandung nilai-nilai perilaku, yang dapat dilakukan atau bertindak secara bertahap dan saling berhubungan antara pengetahuan nilai-nilai perilaku dengan sikap atau emosi yang kuat untuk melaksanakannya, baik terhadap Allah Swt., dirinya, sesama, lingkungan, bangsa, dan negara serta dunia Internasional. 


\section{METODE PENELITIAN}

\section{Desain Penelitian}

Desain penelitian yaitu proses yang diperlukan dalam merancang penelitian dan pelaksanaan penelitian agar pertanyaanpertanyaan yang ada bisa dijawab. Penelitian yang dilakukan disini menerapkan system kerja sama yang komprehensif antara peneliti dan pihak sekolah. Hasil yang nanti diperoleh adalah hasil penelitian dari kajian yang dilakukan bukan hanya oleh peneliti tetapi juga bersama-sama dengan pihak sekolah terutama guru Bimbingan Konseling.

Dalam penelitian ini ada beberapa langkah penelitian seperti yang disebutkan oleh Arikunto (2006: 22-23). Berkenaan langkah-langkah penelitian, yaitu: (1) menentukan masalah, (2) studi pendahuluan, (3) merumuskan masalah, (4) merumuskan kerangka pikiran, (5) menentukan variabel dan sumber data, (6) menentukan dan menyusun instrumen, (7) mengumpulkan data, (8) analisis data, (9) membuat kesimpulan, dan (10) menyusun laporan.

\section{Data dan Sumber Data Penelitian}

Sumber data adalah unsur utama dalam penelitian. Karena melalui sumber data ini, data-data konkrit dapat diperoleh dan dapat memberikan informasi untuk keperluan penelitian (Masri Singarimbun dan Sopian Effendi, 1999:122). Data ini ada yang primer dan sekunder. Data primer dapat diperoleh dari hasil observasi dan wawancara pribadi dengan pihak terkait, sedangkan data sekunder dapat diperoleh dari buku-buku, majalah, internet, jurnal dan sumber-sumber lainnya yang terkait dengan penelitian. Dan di dalamnya peneliti akan menggunakan pendekatan kualitatif yaitu membahas serta menganalisa kemudian menyimpulkan sebagai kesimpulan final apabila sudah memenuhi pertimbangannya.

Subjek penelitian adalah terapis yang terlibat langsung yaitu sang peneliti dibantu oleh guru BK atau konselor yang ada di sekolah itu untuk menjadi mediasi dalam proses konseling melalui teknik hipnoterapi dengan menggunakan teknik verbal dan non verbal. Sedangkan objek 
penelitiannya adalah siswa yang mempunyai masalah psikologis melalui konseling kelompok dan konseling individu.

\section{Teknik Pengumpulan Data}

Teknik pengumpulan data dalam penelitian ini, menggunakan teknik pengumpulan data sebagai berikut:

a. Observasi yaitu pengamatan dan pencatatan dengan sistematis fenomena-fenomena yang diselidiki (Sutrisno Hadi, 1984:141).

b. Interview (wawancara), yaitu percakapan dengan maksud tertentu. Wawancara ini dilakukan secara mendalam dan terstruktur. Susunan pertanyaan dan kata-kata dalam setiap pertanyaan dapat diperjelas pada saat wawancara berlangsung, disesuaikan dengan kebutuhan dan kondisi lapangan (Masri Singarimbun dan Sopian Effendi, 1999:61).

c. Dokumentasi, yaitu untuk mendapatkan data-data yang diperoleh dalam penelitian ini, dan untuk memperkuat hasil penelitian. Dalam hal ini diperoleh dari buku-buku, majalah, internet, jurnal dan sumber-sumber lainnya yang terkait dengan penelitian.

\section{Teknik Keabsahan Data}

Teknik keabsahan data dalam penelitian ini menggunakan kriteria sebagai berikut:

a. Kredibilitas (kepercayaan) dengan teknik trianggulasi yaitu teknik pemeriksaan teknik keabsahan data yang memanfaatkan sesuatu yang lain (Soetrisno Hadi, 1984:1).

b. Ketekunan dan keajegan pengamatan, yaitu menemukan ciri dan unsur yang terkait dengan situasi yang sangat relevan dengan persoalan yang sedang dicari dan memusatkan kepada hal tersebut secara rinci, (Lexy J. Moleong, 1999:329).

\section{Teknik Analisa Data}

Teknik analisa data adalah suatu proses mengorganisasikan dan mengurutkan data ke dalam pola dan kategori tertentu. Selanjutnya data itu di analisa secara deskriptif agar mendapatkan hasil yang objektif (Lexy J. Moleong (1999:103). Tujuannya untuk menggambarkan pelaksanaan penggunaan teknik hipnoterapi dalam proses konseling. Setelah data-data 
terkumpul maka langkah-langkah selanjutnya adalah analisa data yang diperoleh melalui pendekatan deskriptif kualitatif.

Penelitian kualitatif ini menghasilkan transkip wawancara, catatan lapangan, gambar, tipe rekaman dan lain sebagainya (Kristi Purwandani, 1999:22).

\section{HASIL DAN PEMBAHASAN}

Pada penelitian kualitatif peneliti dituntut dapat menggali data berdasarkan apa yang diucapkan, dirasakan, dan dilakukan oleh sumber data. Pada penelitian kualitatif peneliti bukan sebagaimana seharusnya apa yang dipikirkan oleh peneliti tetapi berdasarkan sebagaimana adanya yang terjadi di lapangan, yang dialami, dirasakan, dan dipikirkan oleh sumber data.

\section{Implementasi Teknik Hipnoterapi Dalam Proses Bimbingan Konseling Islami di MTs Negeri Darma Kuningan}

Penerapan teknik hipnoterapi dalam layanan bimbingan konseling secara umum di MTsN Darma belum maksimal, karena dibutuhkan tenaga ahli yang dalam mendampingi siswa menghadapi tugas perkembangan yang sesuai dengan usianya. Menurut kepala sekolah, penerapan teknik hipnoterapi dalam bimbingan konseling sangat membantu merumuskan dan menemukan secara cepat solusi masalah bagi siswa.

Subjek penelitian adalah terapis yang terlibat langsung yaitu sang peneliti dibantu oleh guru BK atau konselor yang ada di sekolah itu untuk menjadi mediasi dalam proses konseling melalui teknik hipnoterapi dengan menggunakan teknik verbal dan non verbal. Sedangkan objek penelitiannya adalah siswa yang mempunyai masalah psikologis melalui konseling kelompok dan konseling individu. Yang dilakukan dalam konseling kelompok adalah membuat empat kelompok dalam kelas kemudian tiap-tiap klien/siswa pada tiap-tiap kelompok mengajukan masalah (berkaitan dengan belajar) yang dihadapinya dengan di tulis pada kertas. Masalah tiap-tiap kelompok kemudian diidentifikasi dan dirumuskan menjadi tiga masalah yang dominan yang merupakan masalah yang dirasakan oleh semua klien/siswa. Proses aplikasinya dengan menggunakan hipnoterapi massal. Sedangkan dalam 
konseling individu proses aplikasinya dilakukan langsung kepada klien secara face to face yang mempunyai masalah dengan menggunakan teknik hipnoterapi pada masing-masing klien/siswa.

Penerapan hipnoterapi kepada klien/siswa yang mengalami masalah phobia di MTs Negeri Darma Kuningan ada 4 siswi dilakukan oleh peneliti dan didampingi guru BK. Proses aplikasinya menggunakan konseling kelompok sekaligus pada 4 siswi yang mengalami phobia (phobia binatang kecoa, gelap, mata pelajaran matematika dan makan nasi). Sedangkan dalam konseling individu penerapan hipnoterapi dilakukan secara perorangan. Ada 3 klien/siswa yang mengalami masalah berbeda yaitu masalah stres pasca trauma, malas belajar dan sulit untuk menghapal.

Setelah proses terapi selesai, orang tua kemudian biasanya diberikan edukasi berupa teknik-teknik terapi hypnosis tertentu yang nantinya dipergunakan untuk membantu pasca hipnoterapi yang dialami anak dan benar-benar bisa dihilangkan.

Dalam implementasinya, proses hipnoterapi ada unsur relaksasi, dimana proses ini diiringi dengan berdoa dan dzikir sebelum di hipnosis. Ketika dalam keadaan relaksasi, otak menampakkan gelombang alfa, dimana kondisinya dalam keadaan rileks, tetapi siaga melakukan sesuatu. Untuk merelaksasikan diri bisa melalui duduk tafakur dan berdzikir, dimana hal ini dapat membangkitkan respon relaksasi. Dzikir itu dapat menjadi salah satu fokus (kata-kata yang menjadi titik perhatian) dalam proses penyembuhan diri dari kecemasan dan ketakutan. Frase fokus ini kemudian dikombinasikan dengan respon relaksasi.

Proses hipnoterapi dalam konseling islami tidak mengubah keyakinan seseorang dan tidak berkenaan dengan magic ataupun gendam (ilmu hitam) seperti yang selama ini disalahartikan oleh banyak kalangan. Proses hipnoterapi yang dilakukan diiringi dengan dzikir dan doa serta bacaan Al-Qur'an dengan tujuan untuk menambah keyakinan yang kuat (keimanan). Bahwa sesungguhnya yang menyembuhkan adalah Allah Swt., bukan terapis karena teknik hipnoterapi adalah sebagai alat bantu di dalam proses penyembuhan. 


\section{Faktor-Faktor Yang Menjadi Pendukung dan Penghambat Penerapan Teknik Hipnoterapi Dalam Proses Bimbingan Konseling Islami}

Faktor pendukung atau kelebihan dari hipnoterapi adalah metode tercepat dalam penyelesaian masalah dengan relaksasi tubuh. Sedangkan penghambatnya tidak semua guru BK kompeten dalam pelaksanaan hipnoterapi dan membutuhkan pelatihan-pelatihan. Faktor pendukung dari hipnoterapi harus ada kesediaan dari klien dan bukan paksaan dengan suasana yang mendukung dan adanya komunikasi. Faktor penghambatnya, karena tidak ada guru BK yang kompeten dalam menggunakan teknik hipnoterapi maka harus mendatangkan ahli dan mahalnya biaya pelatihan.

Yang menjadi penghambat lancarnya pelaksanaan hipnoterapi yaitu kedua orangtuanya, ayah dan ibu, tidak bersedia bertemu terapis untuk menjalani sesi wawancara mendalam dan konseling. Syarat ini sangat penting untuk dipenuhi. Biasanya bila salah satu orangtua tidak bersedia atau berkenan hadir maka kami biasanya akan mempertimbangkan melakukan hipnoterapi pada anak mereka. Syarat ini tentu tidak berlaku bagi orangtua tunggal (single parent).

Faktor pendukung yang lainnya adalah ketersediaan pihak sekolah untuk melakukan penelitian secara inten karena sangat membantu pihak sekolah khususnya guru BK dalam menyelesaikan masalah-masalah siswa terutama dalam mengidentifikasi dan merumuskan masalah-masalah siswa melalui teknik hipnoterapi. Selain itu faktor pendukung diterapkannya hipnoterapi, siswa sangat antusias dalam proses konseling melalui hipnoterapi sehingga memudahkan peneliti untuk secara mendalam menerapkan teknik hipnoterapi.

\section{Dampak Keberhasilan Implementasi Teknik Hipnoterapi Dalam Bimbingan Konseling Islami Terhadap Pembentukan Karakter Siswa.}

Dampak hipnoterapi dalam bimbingan konseling islami terhadap karakter siswa tidak begitu memberikan kontribusi secara ideal, karena keterbatasan waktu yang diberikan pihak sekolah, akan tetapi melalui beberapa sesi yang diterapkan melalui hipnoterapi individu dan kelompok, dampaknya bagi klien banyak yang merasakan suatu perubahan yang signifikan. Masalahmasalah kilen yang menghambat proses pembelajaran seperti trauma, malas dalam belajar, phobia, stres, susah untuk menghapal, minder, kurang percaya diri 
dan masalah-masalah psikhis lainnya alhamdulillah melalui teknik hipnoterapi bisa teratasi kelihatan dari hasil evaluasi di kelas, walaupun tidak secara maksimal karena beberapa hambatan teknis dari pihak sekolah dan keterbatasan waktu yang diberikan kepada peneliti.

Perubahan-perubahan pada diri klien terlihat dari sifat dan perilakunya yang menunjukan keceriaan dan motivasi dalam belajarnya, sholat berjamaah (duha dan duhur) di sekolahpun rajin menurut guru BK-nya, bahkan klien/siswa menunjukan sikap dan karakter yang baik dalam kelas dan pergaulan dengan teman-temannya. Hal ini menunjukan bahwa penggunaan teknik hipnoterapi dalam bimbingan konseling islami memberikan kontribusi yang sangat signifikan terhadap pembentukan karakter klien/siswa di sekolah.

Hasil wawancara dengan Guru BK, dia menjelaskan bahwa teknik hipnoterapi akan mampu mengubah karakter siswa dengan cara mengubah mindset siswa ketika siswa merasa minder dalam bergaul dan meningkatkan rasa kepercayaan diri dan enjoy dalam berinteraksi.

\section{E. KESIMPULAN}

Berdasarkan hasil penelitian yang penulis lakukan tentang “implementasi layanan bimbingan dan konseling islami melalui teknik hipnoterapi dalam membentuk karakter siswa”, maka dapat diambil kesimpulan sebagai berikut:

1. Subjek penelitian adalah peneliti yang terlibat langsung dibantu oleh guru BK atau konselor yang ada di sekolah itu untuk menjadi mediasi dalam proses konseling melalui teknik hipnoterapi. Sedangkan objek penelitiannya adalah siswa yang mempunyai masalah psikologis melalui konseling kelompok dan konseling individu. Penerapan teknik hipnoterapi dalam proses bimbingan dan konseling islami di sekolah sangat membantu dalam memotivasi, membimbing dan mengoreksi penyelesaian permasalahan siswa. Penerapan teknik layanan bimbingan konseling islami walaupun belum maksimal akan tetapi penerapan teknik ini sangat membantu mengidentifikasi, merumuskan dan menemukan secara cepat solusi masalah bagi siswa. 
2. Faktor yang menjadi pendukung penerapan teknik hipnoterapi dalam bimbingan konseling islami adalah ketersediaan pihak sekolah untuk melakukan penelitian secara inten karena sangat membantu pihak sekolah khususnya guru BK dalam menyelesaikan masalah-masalah klien/siswa terutama dalam mengidentifikasi dan merumuskan masalah-masalah siswa melalui teknik hipnoterapi. Selain itu dalam prosesnya siswa mampu berkomunikasi tanpa ada hambatan bahasa dan mampu fokus dalam menjalani sesi terapi serta ada kemauan dan motivasi. Sedangkan faktor penghambatnya adalah kedua orangtuanya, ayah dan ibu, tidak bersedia bertemu terapis untuk menjalani sesi wawancara mendalam dan konseling. Syarat ini sangat penting untuk dipenuhi.

3. Dampak hipnoterapi dalam bimbingan konseling islami terhadap karakter siswa tidak begitu memberikan kontribusi secara maksimal, karena keterbatasan waktu yang diberikan pihak sekolah, akan tetapi melalui beberapa sesi yang diterapkan melalui hipnoterapi individu dan kelompok, dampaknya bagi klien banyak yang merasakan suatu perubahan yang signifikan. Masalahmasalah kilen yang menghambat proses pembelajaran seperti trauma, malas dalam belajar, phobia, stres, susah untuk menghapal, minder, kurang percaya diri dan masalah-masalah psikhis lainnya alhamdulillah melalui teknik hipnoterapi bisa teratasi kelihatan dari hasil evaluasi di kelas. Perubahanperubahan pada diri klien terlihat dari sifat dan perilakunya yang menunjukan keceriaan dan motivasi dalam belajarnya, sholat berjamaah (duha dan duhur) di sekolah, bahkan klien/siswa menunjukan sikap dan karakter yang baik dalam kelas dan pergaulan dengan teman-temannya.

\section{DAFTAR PUSTAKA}

Almatin, Isma. 2010. Dahsyatnya Hypnosis Learning : Untuk Guru dan Orang Tua. Yogyakarta: Pustaka Widyatama.

Arikunto, Suharsimi. 2006. Prosedur Penelitian Suatu Pendekatan Praktik. Jakarta: Rineka Cipta.

Az-Zahrani, Musfir bin Said. 2005. Konseling Terapi. Penerjemah: Sari Narulita \& Miftahul Jannah. Jakarta: Gema Insani. 
Ahyadi, Abdul Azis. 1991. Psikologi Agama. Bandung: Sinar Bintang.

Faqih, Aunur Rahim. 2004. Bimbingan dan Konseling dalam Islam. Yogyakarta: LPPAI UII Press.

Hunter, C. Roy. 2015. Seni Hipnoterapi (penguasaan teknik yang berpusat pada klien), Terj. Paramita, Jakarta: Indek.

Hallen. 2002. Bimbingan Dan Konseling. Jakarta: Ciputat Pers.

Kahija. 2007. Hipnotherapi : Prinsip-prinsip Dasar Praktek Psikotherapi,. Jakarta: Gramedia Pustaka Utama.

Lickona, Thomas. 2012. Character matters (persoalan karakter): bagaimana membantu anak mengembangkan penilaian yang baik, integritas, dan kebijakan penting lainnya/penterjemah, Juma Abdu Wamaungo \& Jean Antunes Rudolf Zien. Jakarta: Bumi Aksara.

Mappiare, Andi. 1996. Pengantar Konseling dan Psikoterapi, Jakarta: Raja Grafindo Persada.

Moleong, Lexy J. 1999. Metode Penelitian Kualitatif, Bandung: Remaja Rosdakarya.

Masdudi. 2015. Bimbingan dan Konseling Perspektif Sekolah. Cirebon: Nurjati Press.

Surya, M. 2004. Psikologi Pembelajaran dan Pengajaran. Bandung: Pustaka Bani Quraisy.

Tohirin. 2007. Bimbingan dan Konseling di Sekolah dan Madrasah. Jakarta: Rajawali Pers.

Willis, Sofyan S. 2004. Konseling Individual Teori dan Praktek. Bandung: Alfabet. 
